\title{
Business competitiveness from the business profile
}

\section{Competitividad empresarial a partir del perfil del empresario}

PLASCENCIA-CUEVAS, Tania Nadiezhda*†, MADRIGAL-HERRERA, Pedro, RIVERA-RIVAS, Laura Talina and ARAIZA-LÓPEZ, Celia Tonanzin

Universidad Autónoma de Nayarit

ID $1^{\text {st }}$ Author: Tania Nadiezhda, Plascencia-Cuevas

ID ${ }^{\text {st }}$ Coauthor: Pedro, Madrigal-Herrera

ID $2^{\text {nd }}$ Coauthor: Laura Talina, Rivera-Rivas

ID $3^{\text {rd }}$ Coauthor: Celia Tonanzin, Araiza-López

DOI: $10.35429 / J B A B .2020 .7 .4 .1 .11$

Received September 18, 2020; Accepted December 30, 2020

\begin{abstract}
Undoubtedly, the strategies to promote and encourage MSMEs are aimed at integrating teamwork, adapting new technologies, improving organizational learning processes, making internal processes efficient, but above all, unifying criteria that lead to directly impact on the competitiveness of the same, with the common goal that is to increase productivity and with it, have more resources. However, all of the above mentioned depends directly on who carries out the business management of each business units, therefore, the present research aims to identify and analyze which is the profile of the entrepreneur that allows reaching the desirable indicators for competitiveness, specifically for the municipality of Bahía de Banderas, Nayarit. Among the main results, it was found that formal education is not a determining factor, but that more elements are needed, such as non-formal education, experience and attitudinal competencies.
\end{abstract}

Competitiveness, MSMEs, Business profile

\begin{abstract}
Resumen
Sin duda alguna, las estrategias para fomentar e impulsar a las MIPYMES van encaminadas a la integración del trabajo en equipo, adaptación de nuevas tecnologías, mejoramiento de los procesos de aprendizaje organizacional, hacer eficientes los procesos internos, pero, sobre todo, a unificar criterios que conlleven a impactar directamente en la competitividad de las mismas, con el objetivo común que es incrementar la productividad y con ello, disponer de mayores recursos. Sin embargo, todo lo anterior depende de forma directa de quienes lleva a cabo la gestión empresarial de las unidades de negocio, por lo tanto, el presente trabajo de investigación, pretende identificar y analizar cual es el perfil del empresario que permite alcanzar los indicadores deseables para la competitividad, específicamente para el municipio de Bahía de Banderas, Nayarit. Dentro de los principales resultados se encontró que no es determinante el poseer educación formal, sino que se necesitan más elementos, tales como la educación no formal, la experiencia y las competencias actitudinales.
\end{abstract}

Competitividad, MIPYMES, Perfil empresarial

Citation: PLASCENCIA-CUEVAS, Tania Nadiezhda, MADRIGAL-HERRERA, Pedro, RIVERA-RIVAS, Laura Talina and ARAIZA-LÓPEZ, Celia Tonanzin. Business competitiveness from the business profile. Journal-Business AdministrationMarketing; Accounting. 2020. 4-7: 1-11

\footnotetext{
* Correspondence to Author (email: tania.plascencia@uan.edu.mx)

$\dagger$ Researcher contributing as first author
} 


\section{Introduction}

Bahía de Banderas is a tourist paradise in the Mexican Pacific, a place that is gaining greater national and international fame, which has allowed various products and services to be introduced in a relatively short period of time, growth has led to the population increase rapidly and, furthermore, the demand for an improvement in their quality of life. However, this immeasurable growth has also brought with it the start-up of different companies that have had a very short life, or failing that, have not experienced any growth, which have not had a favorable impact on business competitiveness and have not served to create jobs in a sustained way, so it is necessary to be able to determine what factors could be those that directly affect this situation.

In this sense, there is evidence that in order to influence business competitiveness, various factors and indicators must be taken into account, some of these are exogenous to the organization and therefore only depend on its ability to adapt to assimilate and achieve them. On the other hand, endogenous indicators make the difference and make each company an entity that cannot be replicated, these range from organizational processes, sales and market strategy and, of course, valuable human resources; But something that can determine the course is the managerial capabilities of the person who manages all the business of the company.

In this sense, the general objective of this research work is to identify and analyze what are the minimum characteristics that the entrepreneur must possess, which can allow achieving the desirable indicators for competitiveness, since the managerial capacities that are determined depend on this profile. They are going to print on business management and are the ones that will determine the future of companies, the object of study is the MSMEs located in the municipality of Bahía de Banderas, Nayarit. Among the main results obtained, it was found that having formal education is not decisive, whether or not in the economic-administrative area, but that more elements are needed, such as non-formal education, experience and attitudinal skills.

\section{Business Competitiveness}

Competitiveness is undoubtedly an aspect that is becoming increasingly important in the development of companies, this derived from the high demands of the current economic environment and the high competition between companies, which are forced to maintain and increase their participation in the market, through constant innovation of products and production processes, favoring cost optimization and continuous increase in productivity (Saavedra, 2012).

The Mexican Institute for
Competitiveness (IMCO) defines competitiveness as the ability of a region to attract and retain talent and investment. To do this, it suggests that these two objectives must be achieved, creating comprehensive conditions that allow people and companies to maximize their productive potential. In addition, the countries must see their level of well-being increased steadily, above the intrinsic possibilities offered by their own resources and their technological and innovation capacities. (IMCO, 2013).

According to the World Economic Forum, the concept of competitiveness involves static and dynamic components, although the productivity of a country is clearly determined by the ability to sustain its income levels, it is also one of the central determinants of investment returns, which is one of the key factors to explain a growing economy (World Economic Forum, 2009) cited in (Saavedra, 2014).

In relation to business competitiveness, for Saavedra (2012), the competitiveness of a company depends on productivity, profitability, competitive position, participation in the internal and external market, inter-company relations, the sector and regional infrastructure and the macroeconomic environment. Citing Porter (1990) and Krugman (1994), Saavedra points out that the nations are not the ones that compete, but the companies, because of what makes a country competitive, the competitive companies that exist in it, so they become the fundamental basis in the analysis of competitiveness. 


\subsection{Indicators of business competitiveness.}

Competitiveness, when analyzed, has always required to be measured, for this there have been many authors and scholars on the subject, who have tried to determine methodologies or models for measuring it.

Saavedra (2014), based on Rubio and Aragón (2006), determines the critical resources of competitiveness, these being the following:

- $\quad$ Technological resources, referring to the experience in the application of new technologies, with human, scientific and technical resources for their development.

- Innovation, which consists of the development of new products, services or production processes, to respond to the needs of customers, adaptation to changes in the environment and achieve the objectives of the company.

- Commercial resources or marketing skills, aimed at better knowledge of the market and customers, allowing customer loyalty and differentiation from the competition.

- Human resources, where it is considered important to attract qualified candidates, retain and motivate current employees and establish formulas that help them grow and develop within the company.

- Management capabilities, which consist of the responsibility to choose and implement different strategic options of the company and their ability to adapt to change. This resource being one of the most important, in characterizing the profile of the employer, in determining competitiveness, as will be seen later in this study.

- Financial resources, which refer to the aspects of short and long-term financial planning, as well as the negotiation capacity to obtain financing.

Culture, referring to the set of habits, beliefs, expectations and values shared by all members of the organization. This resource emphasizes that culture guides the behavior of the people who are part of the company, lays the foundations of procedures and helps maintain internal cohesion.
- $\quad$ Quality of the product or service, which consists in achieving conformity of the set of characteristics and attributes of a product-service, with the needs and expectations of the buyer, following total quality standards.

- The critical resource referring to managerial capacities, takes on great importance in the relationship of the employer's profile, since it is precisely that resource, it is the one that is closely related to the personality and leadership characteristics of the manager, depending on the levels of competitiveness of your company.

According to Ramírez et al. (2017), in every organization it is essential to have a competent staff for the fulfillment of its goals and objectives. In the case of managers, their competence, having the ability to work in a team, interpersonal relationships and problem solving, is especially necessary, since they have the ability to manage, delegate, innovate and have a broad vision of the organization. In this way, the training of managers assumes a predominant role, since it seeks that the training of staff focuses on the development of management skills, knowledge of the organization, the identification of problems, their analysis and resolution of complex problems, in a dynamic organizational context, trying to develop skills and abilities.

On the other hand, Chinchilla and Cardona (1999), cited in Ramírez et al. (2017), deduce that managerial skills or abilities are the essential tool to ensure the competitiveness of companies and classify them into three sections:

\footnotetext{
- Strategic competences: related to business vision, problem solving, resource management, customer orientation, network of effective relationships and negotiation.

- Intra-strategic competences: that have to do with communication, organization, empathy, delegation, coaching, teamwork.

- Personal efficacy skills: referred to proactivity (initiative, personal autonomy), self-government (discipline, concentration, self-control), personal management (time management, stress management, risk management) and personal development.
} 
Zevallos (2007) cited in Saavedra (2014), carried out a study about the restrictions of the business competitiveness environment in Latin America (Argentina, Bolivia, Chile, Colombia, Costa Rica, El Salvador, Panama and Venezuela), where the Most relevant findings were the following:

- $\quad$ More than $50 \%$ of entrepreneurs have a university education.

- More than $50 \%$ of entrepreneurs have more than ten years of business experience.

- $\quad$ The average age of entrepreneurs is over 40 years old.

- $\quad 70 \%$ of entrepreneurs on average belong to the male gender.

These results lead us to think about how the profile of the entrepreneur influences the determination of the level of competitiveness of a company and for this it is that, in this study, we try to characterize said profile, to analyze its relationship with business competitiveness.

\section{Characteristics of the employer's profile}

The dynamic and complex society of these times, has led to the organizational and business schemes traditionally known in both micro, small, medium and large companies, begin to be little functional and are in some cases, even obsolete, including the ways in which Leaders and managers within these organizations exercise their functions to achieve the objectives set. It seems that it is no longer enough to plan, organize, direct and control, even assertiveness in the required communication channels, since now it is essential to add new characteristics and elements that provoke, lead or facilitate new processes of change, incorporating a Innovative thinking, since in effect, innovation, the basis of transformation, is precisely in the new knowledge society. According to Gil (2017), there are three elements that can influence the success or failure of a company, knowing in advance that there are very diverse factors, the author considers that the first of the three refer to those related to non-factors. controllable by the company (exogenous), the latter as those related to internal and structural factors of the company (endogenous) and the third, those related to the characteristics or personality elements of the businessmen or entrepreneurs.
It is precisely in the latter, where the profile of the employer plays a very important role in achieving the objectives set and the success in the company, where the characteristics that stand out are the drive (initiative, being ready for competition, power adaptation, etc.), influence (open, helpful, persuasive, etc.) and compliance (avoid antagonisms, systemic mind, etc.)

There are several theories related to the entrepreneur profile, which according to Veciana (1999) cited in Il Sung (2015), there are four theoretical approaches that refer to the subject of entrepreneurship, which do not seek to explain the process of business creation, but the role that the entrepreneur plays in it, these are:

- Economic approach, which explains the phenomenon of business creation due to economic rationality at the level of the entrepreneur, company or economic system.

- $\quad$ Psychological approach, which analyzes the entrepreneur as a person, his profile and the conditions of successful entrepreneurs, focusing on his personal characteristics.

- Socio-cultural or environmental approach, which examines social, political, family factors and the influence of institutional support on the entrepreneur's decision to create his own company.

- Managerial approach, which observes the development within the company once established, focusing on the characteristics of the company and its organization.

According to Il Sung (2015), the strongest traits or most representative characteristics that define an entrepreneur are: innovative, creative people, see opportunities where others only perceive routine, perceive excessive risk, including failure, and take their business activities such as gambling, with the awareness of being able to lose everything, or be the one who wins the most. In the following table, Christersen (1994), cited in Il Sung (2015), selects the main attributes of entrepreneurs, collecting several authors, who point out the main or fundamental characteristic that, according to each one, defines an entrepreneur: 


\begin{tabular}{|l|l|}
\multicolumn{2}{|c|}{$\begin{array}{c}\text { Author } \\
\text { Stuart Mill (1848) }\end{array}$} \\
\hline Weber (1917) & Source of formalerance \\
\hline Schumpeter (1934) & Innovation and initiative \\
\hline Sutton (1954) & Responsibility \\
\hline Hartman (1959) & Formal authority \\
\hline McClelland (1961) & $\begin{array}{l}\text { Risk tolerance and need for } \\
\text { achievement }\end{array}$ \\
\hline Davids (1963) & $\begin{array}{l}\text { Ambition, independence, } \\
\text { responsibility and self- } \\
\text { confidence }\end{array}$ \\
\hline Palmer (1971) & $\begin{array}{l}\text { Assumption and control of } \\
\text { risk }\end{array}$ \\
\hline Winter (1973) & Lust for power \\
\hline Borland (1974) & Internal perceived control \\
\hline Liles (1974) & Need for achievement \\
\hline Gasse (1977) & Oriented by personal values \\
\hline Timmons (1978) & $\begin{array}{l}\text { Self-confidence, innovation- } \\
\text { oriented }\end{array}$ \\
\hline Sexton (1980) & $\begin{array}{l}\text { Energy, ability to cope with } \\
\text { problems }\end{array}$ \\
\hline Welsh y White (1981) & $\begin{array}{l}\text { Need for achievement, risk } \\
\text { taking, responsibility and }\end{array}$ \\
\hline commitment \\
\hline Dunkelgerg y Cooper (1982) & $\begin{array}{l}\text { Independence, growth } \\
\text { oriented }\end{array}$ \\
\hline Fernal y Solomon (1986) & Oriented by personal values \\
\hline Winslow y Solomon (1987) & Slightly sociopathic \\
\hline & \\
\hline
\end{tabular}

Table 1 Main attributes of the entrepreneur Source: Christersen (1994), cited in Il Sung (2015)

\subsection{The profile of the entrepreneur in the framework of MSMEs}

The entrepreneurial process is the result of the interaction of multiple variables, where evidently business creation, innovation, business networks, risk taking, among others, can be found. Based on these guidelines, it can be argued that there is no single model that identifies the profile of the entrepreneur (Bojica, 2012) and in turn is applicable to all contexts; However, specifically in the framework of MSMEs, due to their structural characteristics, they suffer from disadvantages compared to large companies, because they do not have economies of scale and have a shortage of human, technological and financial resources, to carry carry out their production processes (Camisón, 2001), which determines to a great extent, their permanence in the market, which many times is very short; On the other hand, these types of companies are characterized by being generally made up of a family structure, most of which use traditional production systems, where the owner is usually the administrator; These companies generally tend to be a reflection of their owners, that is, their individual strengths and weaknesses will be reflected in the type of company they manage (Rodríguez, 2002).
Due to these particularities, it is necessary to focus the characteristics of the entrepreneur's profile in these types of companies, which are associated with those who successfully direct their growth. It is proposed to specify in this theoretical section, the following according to various authors:

Durand (2008) establishes four types of business profile: beginners, who are students who start an investment project, initiates, who usually come from families with companies with inherited knowledge, mature ones, who represent a balance between knowledge and professionalization, and, lastly, the rebels, who are at greater risk because in many cases they do not have a university degree and their business arises from an outburst motivated by generating money. Whatever the case, the future entrepreneur must have competencies (knowledge, skills and attitudes), which will define the competitiveness of his company and aware of the personal challenges that the business project entails, he must know the keys to success related to the different stages . They are summarized in Table 2 .

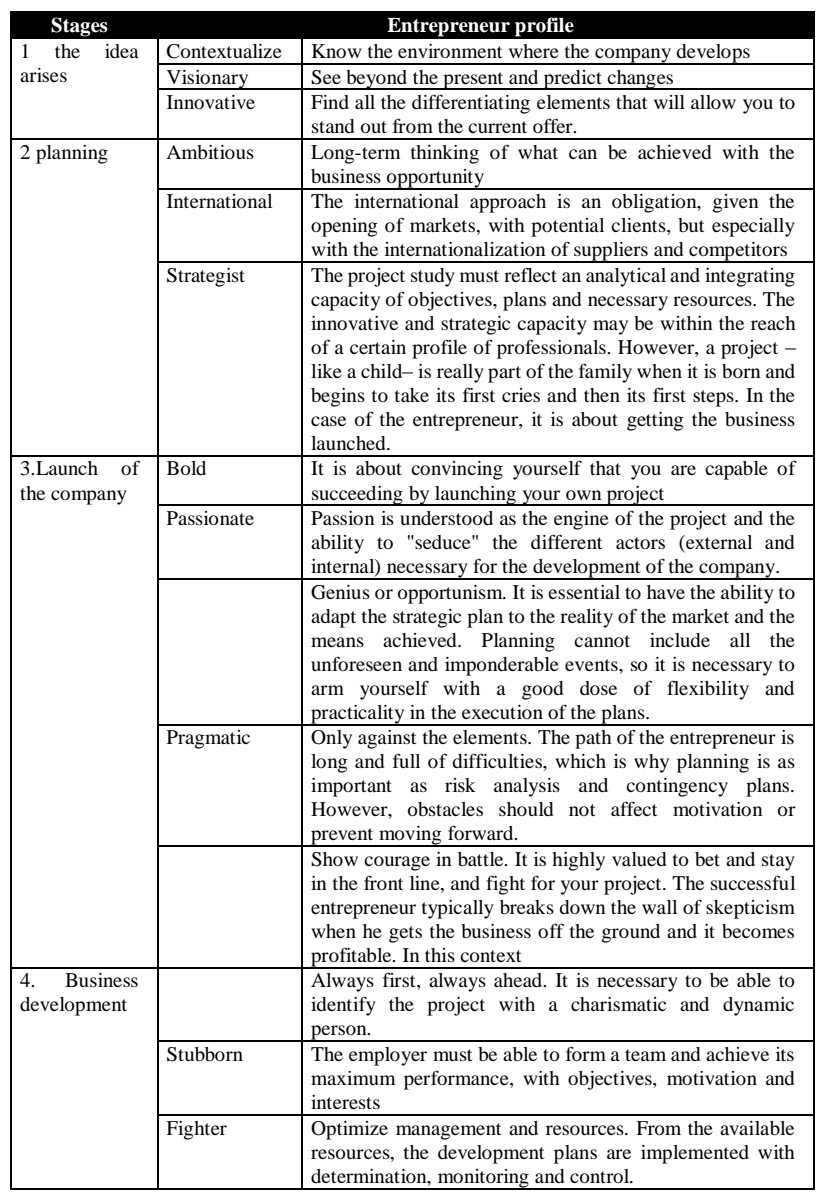

Table 2 Profile of the entrepreneur according to their stages of development

Source: Own elaboration based on Durand (2008) 
Man, T.W.Y ; Lau, T ; Chan, K.F. (2002) warn that micro, small and medium-sized companies are not a reduced version of larger companies and establish their difference in terms of their organizational structure, responses to the environment, management styles and the ways in which they compete with other companies. As a result, competitiveness studies that describe skills profiles and that focus on large companies cannot necessarily be applied to the scale of SMEs, so it is necessary to take into account that, when changing the scale of the organization, their specificities and characteristics change. In this regard, Lans and Mulder (2009) synthesize this idea through the following postulate:

Theoretical models of competence do not necessarily coincide with those effective competences developed in practice. It becomes clear that business performance at the small business level is related to entrepreneurial competence and skill development at the individual level.

Ramírez (1996), refers to the profile of the small entrepreneurial entrepreneur, pointing out the following characteristics:

- $\quad$ Knowledge of your company, both in terms of purposes and needs, means and possibilities

- Knowledge of the work, the activity in general and the specific activities carried out in the organization

- $\quad$ Sense of responsibility

- Ability for human relations (both for staff and their clients)

- Aptitude to instruct, based on their experience, their needs, awareness and mastery of the problems that arise in your company

- Skill for work. Development of a physical and psychological activity capable of withstanding the constant stress of business management

- Ability to improve work methods, update,

- $\quad$ Opening for technology

- Decision and initiative for decision making

- Intellectual capacity, technical and business knowledge

- Defined personality. Emotional balance.

- Moral integrity. It is the basis of the respect and trust of your staff.
- Practic sense. In addition to the analytical sense, you must take action to provide solutions rather than stop at perfection

- Organizational capacity. Know how to distribute their time and daily tasks among their subordinates.

Today, undertaking a business project is an alternative considered as the main jobgenerating activity in the country and a source of income for many people, however, it is important to understand a priori, what are the personal implications, requirements and requirements risks of such a project, such as business skills, technical, commercial, financial and human capacities, as well as the possibilities, the potential for success and the risks of failure, for decision-making in the creation of the company.

\section{Methodology}

The general objective of this research is to identify and analyze what are the minimum characteristics that an entrepreneur must have so that they have a favorable impact on the general indicators of business competitiveness. Consequently, the central hypothesis is raised that the profile of the employer is the key element to influence the competitiveness of MSMEs, since their managerial capacities depend on it. In this sense and using office techniques, a literature review was made, both of business competitiveness indicators and of the general characteristics that, in theory, an entrepreneur of MSMEs should have. In addition, a descriptive cross-sectional study was carried out, since a survey was carried out to MIPYMES located in the municipality of Bahía de Banderas, Nayarit. The survey had the objective of generating some indicators of business competitiveness, however, for the present investigation, only the data that allow showing the characteristics of the entrepreneurs were taken, such as age, gender, level of studies, area of studies, updates , among others, in addition to analyzing whether the company has needed financing or not, this in order to determine if the solvency of the company has any relationship, at least descriptive, with the general profile of the entrepreneur. The application was made to 200 companies, although only 110 questionnaires could be validated. 
Since in the companies that were visited they did not answer any of the essential data for the present investigation, or, failing that, the survey was not answered by the employer or by the general manager of the same. The sample can be considered as representative, since they were applied in most of the towns of the municipality and, in addition, companies of various lines were taken into account. Likewise, three interviews were conducted with randomly chosen entrepreneurs, the interviews were conducted around the life and trajectory of companies from the beginning, how they were formed, the greatest difficulties they consider they have faced and how they have come to resolve their main conflicts, it was used as an essential requirement that they were registered in the SHCP, since formality is considered essential to achieve competitiveness indicators.

\section{Results}

Much has been written that Bahía de Banderas, in recent decades has increased its popularity as one of the favorite destinations within the Mexican Republic. It is a destination mainly known as sun and beach, it has all the infrastructure to accommodate tourists of different socioeconomic levels and what it may lack, such as an airport, it makes up for with its proximity to the municipality of Puerto Vallarta. . For this reason, most of the companies located in the place are directed directly or indirectly to the tourism sector, with which the destination is in constant growth and movement, thus being necessary the supply of goods and services not only in quantity but also in quality, giving priority to what the visitor demands in order to extend their stays and make their visits frequent.

In this context, 110 companies were surveyed, of which 102 are micro-companies and only 8 are small, medium-sized companies were not surveyed because many of those in Bahía de Banderas belong to a group of companies such as corporate or franchise, such is the case of supermarkets. All are in a regular situation with the Ministry of Finance and Public Credit, either as an individual or a legal entity, and this was a requirement for the company to be included in this study. As can be seen in figure 1, companies have commerce as the predominant activity (63), 45 companies belong to the service sector and only 2 companies are industries, it is important to clarify that the study area has very few industries.
It can even be said that the something is lacking, since the industry could generate various jobs. Within the companies are restaurants, tortillerías, groceries, laundries, butchers, auto parts stores, hardware stores, just to mention a few.

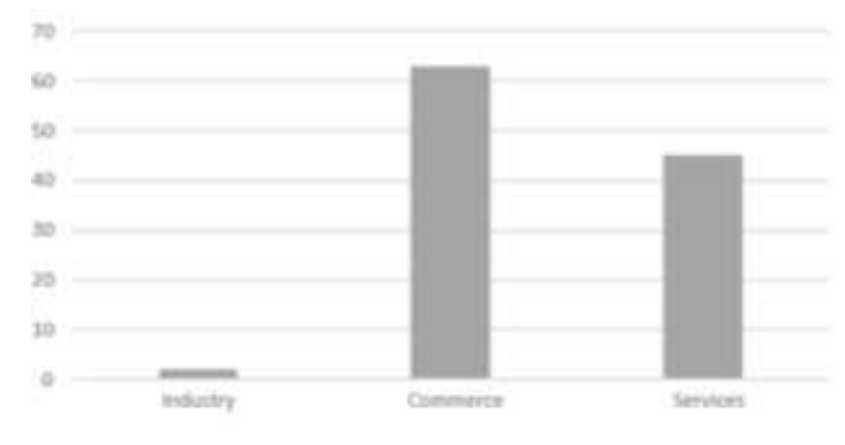

Figure 1 Turnover of the surveyed companies Source: Own elaboration based on survey results

Due to the characteristics of the environment, an obligatory question was whether or not the company is family-owned, since there are many trades that are passed from generation to generation, therefore, in Figure 2 it can be seen that $63 \%$ of companies respondents are family members while $37 \%$ are not. This can be considered relevant data because the family businesses in the sample are those with the longest seniority, the average age of family businesses is 12 years, which could indicate a greater degree of specialization in their administrative and management processes. production.

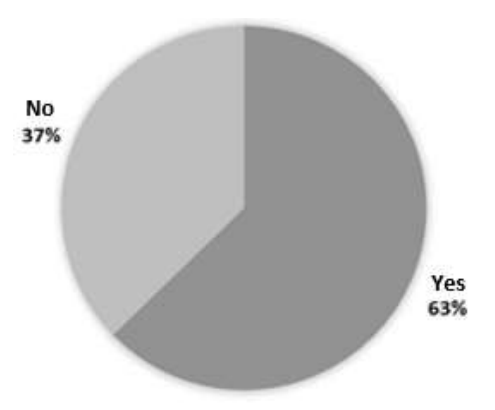

Figure 2 Family business

Source: Own Elaboration based on survey results

The surveyed companies state that they have a medium and medium-high control regarding the management of their finances, since they point out that in high seasons they try to leave the payments for the year covered, and they can consider the rest as profits. 
In this regard, $15 \%$ indicate that, if they have needed financing, $61 \%$ have not needed it, and $24 \%$ preferred not to answer the question. The financing mechanisms were through multiple banks, family members or the providers themselves, none of them resorted to government agencies. Of the $15 \%$ who state that, if they have needed financing, they argue that the main destination is to pay debts with suppliers for raw materials or for the maintenance of their companies, in none of the cases did they state that it was to grow the company. In the case of the $61 \%$ who have not needed financing, they indicate that they use their own resources or a loan from a relative (smaller amounts) but without interest or installments, so they do not count it as being financed, in many cases the family member who supports is the spouse.

As for the characteristics of the employer, it begins with age. The average age is 35 years, however, the mode is between 25 and 26 years as can be seen in Figure 3, this means that most of the entrepreneurs are young, same as for being from the era of technology and innovation may be more open to embrace new business strategies or, perhaps, to incorporate innovative processes into their manual procedures, both in administrative matters and in the production of their goods and / or services.

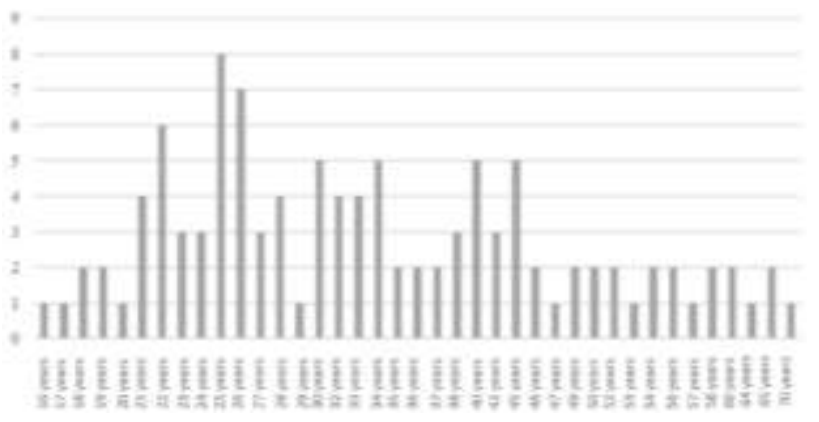

Figure 3 Age frequency of employers

Source: Own Elaboration based on survey results

Regarding gender, 57 are businessmen and 53 are businesswomen, representing 52\% and $48 \%$ respectively. This is also relevant, since there are more and more women entrepreneurs, who are making business work diversify and, above all, the vision is from another perspective.

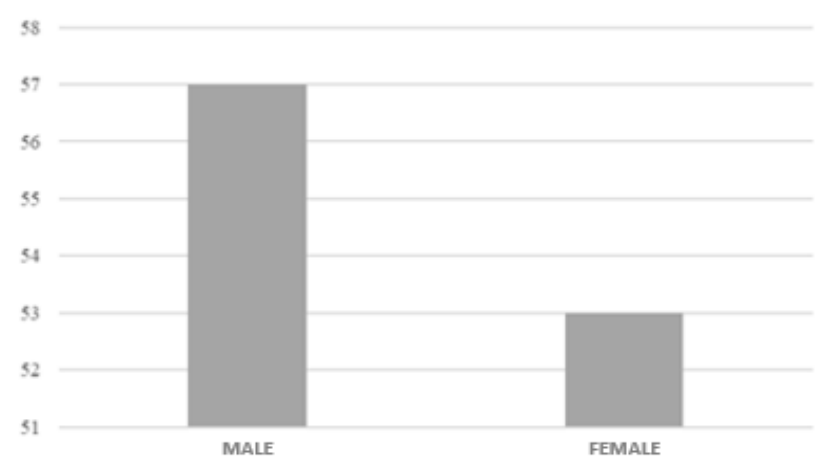

Figure 4 Gender frequency

Source: Own Elaboration based on survey results

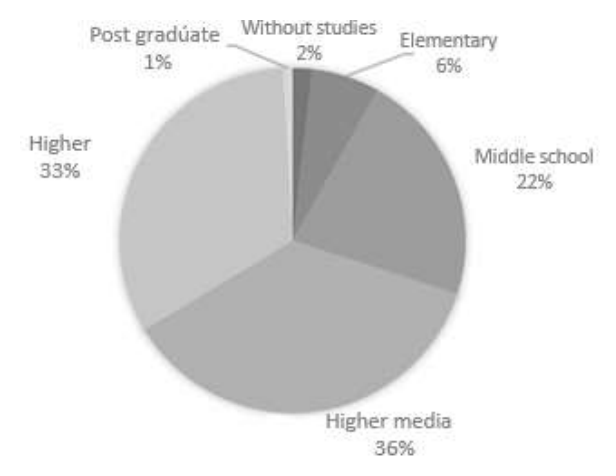

Figure 5 Level of studies

Source: Own Elaboration based on survey results

Regarding the level of studies, as can be seen in Figure 5, 33\% of the surveyed businesswomen have at least completed higher education, $1 \%$ have a postgraduate degree in the economic-administrative area, the $36 \%$ finished upper secondary education, either in preparatory or equivalent high school, $22 \%$ have secondary school, $6 \%$ elementary school and only $2 \%$ said they had no formal education or had taken any refresher courses, they only indicated knowing how to read, write and basic math. At this point it is important to clarify that of those who have higher education studies, only $56 \%$ is in the economic-administrative area, the remaining $44 \%$ is very varied, there are studies in industrial design, architecture, nursing, audiovisual communication, among others degrees obtained. These data are relevant because at least a third of those surveyed have the tools that, strictly speaking, higher education offers, both in formal and non-formal education, the analysis processes and the development of logical thinking.

Table 3 shows the results of the three semi-structured interviews carried out, these were recorded and at the request of the interviewees the names are omitted, they will only be assigned numbering. 
In the aforementioned Table, the specific details of both meeting points and disagreements that the three analyzed cases had will be put. It should be noted that the three cases have different conditions, two with higher education, 1 without completed studies, two men 1 woman, different ages, among other characteristics, this in order to broaden the panorama and the analysis perspective.

\begin{tabular}{|c|c|c|c|}
\hline & Interviewed 1 & Interviewee 2 & Interviewee 3 \\
\hline Age and gender & Male (30 years old) & Female (45 years) & Male (67 years) \\
\hline Level of studies & $\begin{array}{l}\text { Degree in audiovisual } \\
\text { communication }\end{array}$ & 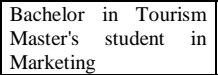 & Primary truncated \\
\hline $\begin{array}{l}\text { Marital status } \\
\text { and number of } \\
\text { children }\end{array}$ & Single (1 child) & Married (no children) & $\begin{array}{l}\text { Married (2 } \text { sons } 3 \\
\text { daughters) }\end{array}$ \\
\hline \begin{tabular}{l|} 
Additional \\
courses
\end{tabular} & \begin{tabular}{|l|l|}
$\begin{array}{l}\text { Boat and boat } \\
\text { maintenance }\end{array}$ \\
\end{tabular} & $\begin{array}{l}\text { Administrative } \\
\text { management }\end{array}$ & $\begin{array}{l}\text { Those of the health } \\
\text { department for food }\end{array}$ \\
\hline Location & New vallarta & Sayulita & Bucerias \\
\hline Company line & $\begin{array}{l}\text { Service } \\
\text { transport) }\end{array}$ & $\begin{array}{|lrr|}\begin{array}{l}\text { Commerce } \\
\text { clothing }\end{array} & \text { (sale } & \text { of } \\
\text { accessories) } & & \text { and } \\
\end{array}$ & $\begin{array}{ll}\begin{array}{l}\text { Service } \\
\text { Restaurant) }\end{array} & \text { (Seafood } \\
\end{array}$ \\
\hline No. of employees & $\begin{array}{l}6 \text { (in high season they } \\
\text { increase) }\end{array}$ & $\begin{array}{l}\text { (in high season they } \\
\text { increase) }\end{array}$ & $\begin{array}{l}5 \text { (in high season they } \\
\text { increase) }\end{array}$ \\
\hline Market Stall & $\begin{array}{l}\text { Boss, but I do what it } \\
\text { takes }\end{array}$ & $\begin{array}{l}\text { I do the administrative } \\
\text { management }\end{array}$ & $\begin{array}{l}\text { Everything, but more } \\
\text { in the kitchen }\end{array}$ \\
\hline $\begin{array}{l}\text { Age of the } \\
\text { company }\end{array}$ & 10 years & 4 years & 16 years \\
\hline Family business & $\begin{array}{l}\text { Yes (my uncle inherited } \\
\text { it) }\end{array}$ & No (recently created) & $\begin{array}{l}\text { Yes (I started, but my } \\
\text { children and wife } \\
\text { work with me) }\end{array}$ \\
\hline $\begin{array}{l}\text { Principal } \\
\text { problem }\end{array}$ & Price of fuel for boats & $\begin{array}{l}\text { Treasury for many cash } \\
\text { sales }\end{array}$ & $\begin{array}{l}\text { Employees, there is a } \\
\text { lot of turnover }\end{array}$ \\
\hline $\begin{array}{l}\text { Promotion and } \\
\text { publicity }\end{array}$ & Social media and flyers & \begin{tabular}{|l|} 
Social networks \\
\end{tabular} & $\begin{array}{l}\text { Word of mouth } \\
\begin{array}{l}\text { Facebook (for the } \\
\text { daughters) }\end{array} \\
\end{array}$ \\
\hline Strategic plan & No & No & No \\
\hline $\begin{array}{l}\text { Short-term goals } \\
\end{array}$ & Finish paying pot & Expand the store & $\begin{array}{l}\begin{array}{l}\text { Pay payroll and } \\
\text { materials }\end{array} \\
\end{array}$ \\
\hline Long-term goals & $\begin{array}{l}\text { Buy more transport } \\
\text { options, motorcycles, } \\
\text { boats, catamaran, etc. }\end{array}$ & \begin{tabular}{|l|} 
Increase sales year after \\
year so that the seasons \\
do not feel so hard. \\
Have your own brand \\
in clothing and \\
accessories r
\end{tabular} & $\begin{array}{l}\text { Retire, let my children } \\
\text { take care }\end{array}$ \\
\hline Financing need & Yes & Yes & $\begin{array}{l}\text { No (I started with } \\
\text { savings and thank God } \\
\text { it has always worked } \\
\text { out) }\end{array}$ \\
\hline $\begin{array}{l}\text { Purchasing } \\
\text { Process }\end{array}$ & $\begin{array}{l}\text { Every day in the } \\
\text { afternoon we buy } \\
\text { everything we need, } \\
\text { especially fuel, we have } \\
\text { a log of each trip, so we } \\
\text { plan what is required }\end{array}$ & $\begin{array}{l}\text { Merchandise arrives } \\
\text { every } 15 \text { days, if there } \\
\text { are not many sales it is } \\
\text { every month. Few } \\
\text { pieces of each product } \\
\text { are purchased. } \\
\text { Inventory is done }\end{array}$ & $\begin{array}{l}\text { My wife and I do the } \\
\text { daily shopping, we } \\
\text { already know what is } \\
\text { busy, it is many years } \\
\text { and we know what } \\
\text { sells the most, we buy } \\
\text { a little more } \\
\text { depending on the day }\end{array}$ \\
\hline Planning process & $\begin{array}{l}\text { We have a computer } \\
\text { system and everything } \\
\text { is written down there, } \\
\text { then we go to the } \\
\text { accountant and she } \\
\text { takes care }\end{array}$ & $\begin{array}{l}\text { We have a point of sale, } \\
\text { so everything is } \\
\text { recorded. }\end{array}$ & $\begin{array}{l}\text { We have a point of } \\
\text { sale, but I have } \\
\text { everything written } \\
\text { down in a notebook }\end{array}$ \\
\hline $\begin{array}{l}\text { Business } \\
\text { learning }\end{array}$ & $\begin{array}{l}\text { Everything I know was } \\
\text { taught to me by my } \\
\text { uncle since I started } \\
\text { working with him as a } \\
\text { "chalán" and I went up. } \\
\text { We have changed some } \\
\text { things. }\end{array}$ & $\begin{array}{l}\text { Well, many things that } \\
\text { I saw in school I apply } \\
\text { them in my own way, it } \\
\text { was difficult for me to } \\
\text { adapt the theory to } \\
\text { reality, one improvises } \\
\text { a lot. }\end{array}$ & $\begin{array}{l}\text { The method was trial } \\
\text { and error (laughs), I } \\
\text { didn't know anything } \\
\text { about restaurants, but } \\
\text { you had to bring "the } \\
\text { goat" to the lady }\end{array}$ \\
\hline $\begin{array}{l}\text { Characteristics of } \\
\text { an entrepreneur }\end{array}$ & \begin{tabular}{|l|} 
Sociable \\
that knows how to move \\
Employee \\
Know the environment
\end{tabular} & \begin{tabular}{|l} 
Sales work \\
Know what you sell \\
Managed \\
Organized \\
Initiative
\end{tabular} & $\begin{array}{l}\text { You win } \\
\text { Know how to talk to } \\
\text { staff } \\
\text { Be thankful } \\
\text { Be, always be } \\
\text { Know what it takes } \\
\text { Want to solve } \\
\text { Don't fall for anything } \\
\end{array}$ \\
\hline $\begin{array}{l}\text { An entrepreneur } \\
\text { is born or made }\end{array}$ & $\begin{array}{l}\text { It is done, they taught } \\
\text { me to be }\end{array}$ & \begin{tabular}{|lr} 
It is done by & the \\
circumstances & that \\
touch you &
\end{tabular} & $\begin{array}{l}\text { You are born, there } \\
\text { are people who know } \\
\text { a lot and study a lot } \\
\text { but who are not good } \\
\text { for business }\end{array}$ \\
\hline $\begin{array}{l}\text { A tip for those } \\
\text { who want to } \\
\text { undertake }\end{array}$ & Try every day & Don't give up fast & $\begin{array}{l}\text { Commit and don't give } \\
\text { up in tough times }\end{array}$ \\
\hline
\end{tabular}

Table 3 Interview results divided by person Source: Own Elaboration based on interviews carried out in March 2019
Once the graphs corresponding to the applied survey and the responses of the interviews carried out were analyzed, it can be seen that, although it is true, formal education is considered the best disciplinary knowledge base and offers the possibility of analyzing complete scenarios. , is not always decisive to carry out the activities that allow entrepreneurship, or else, formal education cannot be considered as a synonym for acquiring skills for entrepreneurship. In this sense, this research agrees with Durand (2008), since in his research he emphasizes that the profile of the entrepreneur is linked to characteristics that are part of the personality, such as tenacity, perseverance, leadership, being a strategist, among others, which are not in all cases learned, but are part of attitudinal skills and are unpredictable. If this is analyzed through the indicators that determine business competitiveness according to Saavedra (2012), there are several that depend directly on the decisions of the employer, among these is the acquisition of technology, the continuous training of human resources and the availability of resources quality, production, internal organization and interaction with suppliers and customers depend on these, with what is considered from the results obtained, which in the order of priority indicators is number one management skills, which could be integrated by training in the sector, the tools acquired from formal education and, in addition, the aforementioned personality qualities, adding emotional intelligence, experience and teamwork skills, which also are an argument for study and discussion on the agenda of the World Economic Forum.

\section{Conclusions}

In the present research, a review of the relevant literature on the subject was first carried out, which will provide theoretical support, mainly to analyze the indicators that intervene for a company to achieve business competitiveness, being aware that there are quantitative and qualitative indicators, which can contribute some subjectivity to the measurement of competitiveness. Likewise, the literature that presents evidence of the profile and characteristics of an entrepreneur was analyzed, since it sought to verify what entrepreneurial skills and business characteristics determine, since an entrepreneur cannot be defined the same, when the activity that develops is incipient or when it has years of experience in the field.

PLASCENCIA-CUEVAS, Tania Nadiezhda, MADRIGALHERRERA, Pedro, RIVERA-RIVAS, Laura Talina and ARAIZALÓPEZ, Celia Tonanzin. Business competitiveness from the business profile. Journal-Business Administration-Marketing; Accounting. 2020 
Following the same order of ideas, the general objective of the research has been to identify and analyze what are the minimum characteristics that an entrepreneur must have so that they have a favorable impact on the general indicators of business competitiveness. Consequently, the central hypothesis is raised that the profile of the entrepreneur is the key element to influence the competitiveness of MSMEs, since their managerial capacities depend on it. To achieve the objective, 110 surveys were conducted with the owners and / or managers of MSMEs located in Bahía de Banderas and, also through a semi-structured interview, 2 businessmen and a businesswoman with different characteristics were interviewed.

In the results, it was found that indeed the profile of the entrepreneur is decisive for the future of the company and thus achieve competitiveness indicators. This profile is not composed solely of formal university education, since only $39 \%$ of those surveyed had it, male entrepreneurs are the majority, but not by much, since they represent $52 \%$ and women $48 \%$, the average age is 35 years and most are part of a family business. The profile of the employer also depends on non-formal education, experience, emotional intelligence and the attitudinal competencies of the personality, which are considered unpredictable and not very replicable; therefore, the hypothesis of the importance of the business profile in business competitiveness is accepted.

\section{References}

Bojica, A.; Ruiz, M. y Fuentes, M.D. (2012), "La adquisición de conocimiento a través de relaciones inter organizativas y la orientación emprendedora: el papel del capital social de segundo grado". Cuadernos de Economía y Dirección de Empresas, vol.15, pp. 141-153.

Cabrera, A., López, P., y Ramírez, C. (2011). La competitividad empresarial: un marco conceptual para su estudio. Universidad Central (documentos de investigación: Administración de Empresas, n.o 4). Bogotá:Universidad Central. Recuperado de https://www.ucentral.edu.co/images/documento s/editorial/2015_competitividad_empresarial_0 01.pdf
Camisón, C. (2001) "La competitividad de la empresa industrial de la Comunidad Valenciana. Análisis del efecto del atractivo del entorno, los distritos industriales y las estrategias empresariales". Triant lo Blanch. Valencia.

Chinchilla, N. \& Cardona, P. (1999). En busca de las Competencias Directiva. El nuevo paradigma que está revolucionando la dirección de personas. Harvard Business Deusto Review, IESE., 10-19.

Christensen, M. A. (1994). The identification of business starters using attitude. Calgary: University of Calgary Press.

Durand, T. (Última revisión, 21 de enero de 2008) El perfil y las habilidades del empresario. Bajo la supervisión del profesor Manuel Bermejo del IE Business School. Versión original del 8 de septiembre de 1999. Última revisión, (R.L.) Editado por el Departamento de Publicaciones del IE. María de Molina 13, 28006 -Madrid, España. http://ocw.ie.edu/ocw/materiales/gestion/GE2_ 113_NF.pdf

Gil, O. L. (agosto 2017) Asociación entre el perfil del empresario y el éxito en el emprendimiento internacional. PAAKAT: revista de tecnología y sociedad versión On-line ISSN 2007-3607. vol.7 no.12. Guadalajara.

http://www.scielo.org.mx/scielo.php?script=sci _arttext\&pid=S200736072017000200003

Il Sung, S., y Duartei, S. (2015). El perfil del emprendedor y los estudios relacionados a los emprendedores Iberoamericanos. Revista Internacional de Investigación en Ciencias Sociales, 11(2), 291314. https://dx.doi.org/10.18004/riics.2015.dici embre.291-314

IMCO. (2013). Índice de Competitividad Internacional del Instituto Mexicano para la competitividad. Retomado de: http://imco.org.mx/wpcontent/uploads/2011/10/indice_de_competitivi dad_internacional_2013.pdf

Krugman, P. (1994). Competitiveness: A Dangerous Obsession,ForeingAffairs, 73 (2) 2844 
Lans, T., \& Mulder, M. (2009). Competenceempirical insights from a small-business perspective. Proceedings of the ECER VETNET conference.

Man, T.W.Y.; Lau, T.; Chan, K.F. (2002). The competitiveness of small and medium enterprises: A conceptualization with focus on entrepreneurial competencies, Journal of Business Venturing 17, no. 2, p.123-142.

Porter, M. (1990). La ventaja Competitiva de las Naciones. México: Vergara.

Ramírez Cavassa Cesar, "El directivo de la pequeña empresa", México, Editorial Pac, 1996, pp. 11-19.

Ramírez, J.; Cerón, H.; Cerón, A.; Maya, N., (2017). Las competencias directivas base de la competitividad empresarial: Un estudio correlacional. Revista Administracion y Finanzas.

Rodríguez Valencia, J. (2002) Administración de pequeñas y medianas empresas. Económico administrativas. International Thomson editores. Quinta edición. ISBN 970686-242-0; México.

Rubio, A. y Aragón, A. (2006). Competitividad y recursos estratégicos en la Pyme.Revista de empresa, julio-septiembre, 17, 32-47

Saavedra, M. L. (2012); Hacia la competitividad de la PYME latinoamericana. Macroproyecto de investigación.

Saavedra, M. L. (2012). Una propuesta para la determinación de la competitividad de la pyme latinoamericana. Pensamiento \& Gestión No. 33, 93-124.

Saavedra, M. (2012). Un análisis del nivel meta de la competitividad en México. XIII Asamblea General de ALAFEC. Buenos Aires, Argentina: ALAFEC.

Saavedra, M. L. (2014). Hacia la determinación de la competitividad de la Pyme Latinoamericana. Macroproyecto de investigación ALAFEC. Publicaciones Empresariales UNAM, 12-40.

Veciana, J. M. (1999). La creación de empresas: Un enfoque empresarial. Colección Estudios Económicos, 33.
World Economic Forum (2009). The Global Competitiveness Report 2009-2010. Geneva.

Zevallos, E. (2007). Restricciones del entorno a la competitividad empresarial en América Latina. San José, Costa Rica: FUNDES. 